\title{
Strategic Development of Business Models: A Case study of the PT. Timah Agro Manunggal in Indonesia
}

\author{
Husnul Haq \\ Department of Business Administration, \\ Universitas Padjadjaran, \\ Bandung, Indonesia \\ Margo Purnomo \\ Department of Business Administration, \\ Universitas Padjadjaran, \\ Bandung, Indonesia \\ Muhamad Rizal \\ Department of Business Administration, \\ Universitas Padjadjaran, \\ Bandung, Indonesia
}

\begin{abstract}
Business Model Canvas manages to make business model simple, and easily understood while capturing the complexities of how enterprises function. The research purpose is to evaluate the business model on a new company used Business Model Canvas (BMC). BMC consists of customer segments, value propositions, channels, customer relationship, revenue streams, key resources, key activities, key partnership, and cost structure. The research method was used qualitative descriptive analysis. The data collected using in-depth interviews and observations. The data analysis using reduction, data display, and conclusion techniques. Analysis SWOT is to evaluate the business model on an PT. Timah Agro Manunggal as agribusiness company. The results show that the nine blocks of the business model canvas can be the initial identification to form a business development strategy. The conclusion of this paper is the business development strategy at PT. Timah Agro Manunggal can be creating a competitive advantage through marketing strategies, collaboration strategies, optimizing partnership relationships with stakeholders. The business model canvas is an effective tool for maximizing the planning of the development of the business model of agribusiness companies for the long term.
\end{abstract}

Keywords: Business model canvas, SWOT analysis, agribusiness company

\section{INTRODUCTION}

The post-industrial 21 centuries are characterized by instability and turbulence in a business environment (Teece, 2010). Companies change not only their products, but also culture, ways of selling, relationships with customers or internal structure. PT. Timah Agro Manunggal (PT. TAM) is an agribusiness company that reclaims damaged land ex-tin mining land in Indonesia. PT. TAM has been operating commercially for 3 years with many ex-tin mining lands that have been reclaimed. As a new company, there are company targets that have not been achieved. Besides that, PT. TAM must immediately form a business model to obtain company goals. Then, PT. TAM needs to formulate effectively to establish the company's business strategy.

Based on initial observations, the market goals of PT. TAM have not been achieved, at the time this research was conducted. Then, this paper aims to identify the internal and external factors 
of the company through an analysis of strengths, weaknesses, opportunities, and threats (SWOT). Then there will be planning and making a business strategy with a business model canvas. Osterwalder \& Pigneur (2010) suggested to develop a business model with reference to Business Model Canvas (BMC).

Business Model Canvas is a strategic management and lean startup template for developing new or documenting existing business models (Hanshaw \& Osterwalder, 2016). It is a visual chart with elements describing a firm's or product's value proposition, infrastructure, customers, and finances (Osterwalder \& Pigneur, 2002). It assists firms in aligning their activities by illustrating potential trade-offs. The Business Model Canvas was initially proposed by Alexander Osterwalder based on his earlier work on Business Model Ontology (Osterwalder \& Pigneur, 2002, 2010). Since the release of Osterwalder's work in 2008, new canvases for specific niches have appeared.

Through the design of BMC at PT. TAM, it will be able to increase profit potential (profit), increase value in the industry, avoid conflicts that occur between stakeholders or collaboration, increase economic growth, improve community welfare, create jobs, and large industrial risk reduction (Maurya, 2014; Zolnowski, Weiß, \& Böhmann, 2014). The aim of this research is to identify potential and formulate the development policy of PT. TAM. Then, a business model can be developed that can be linked to business development, marketing programs, anticipation of competitors, and mature strategies to compete in the post-mining land reclama industry (Hanshaw \& Osterwalder, 2016; Maurya, 2014; Murray \& Scuotto, 2016; Toro-Jarrín, Ponce-Jaramillo, \& Güemes-Castorena, 2016).

\section{LITERATURE REVIEW}

The term of a business model first appeared in an academic article by Bellman Clark et al. in 1957 and in the title and abstract by Jones in 1960 (Osterwalder, 2004). The business model has been referred to as architecture, design, pattern, plan, method, assumption, and statement (Johnson, 2012; Vial, 2016). Osterwalder \& Pigneur (2010) stood out among the others as they did not only offer business model definition and components, but also a visualization of business model. Business Model Canvas allows business model to be simple, relevant and intuitively understandable, while not oversimplifying the complexities of how enterprises function (Osterwalder \& Pigneur, 2010).

The Canvas becomes a shared language and a useful tool for stakeholders to talk about business model. The Business Model Canvas and the definition of the nine building blocks are presented below.

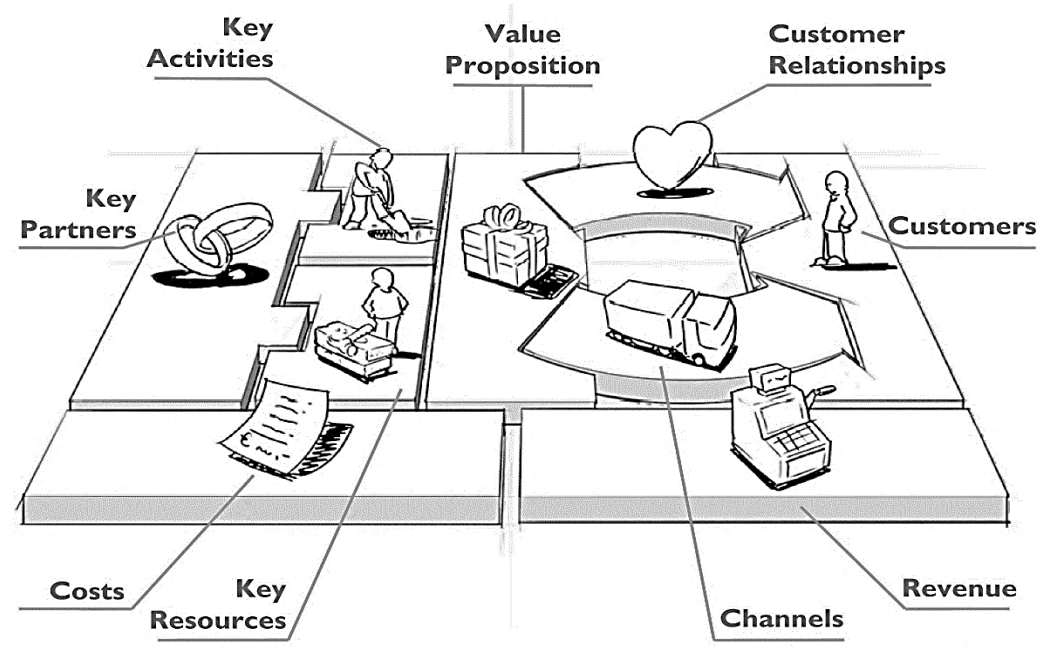

Fig. 1. Business Model Canvas Framework 
The nine building blocks of the Business Model Canvas referred by Osterwalder \& Pigneur (2010):

1) Customer Segments: The different groups of people or organizations an enterprise aims to reach and serve.

2) Value Proposition: The bundle of products and services that create value for a specific Customer Segment. Value may be quantitative (e.g., price, speed of service) or qualitative (e.g., design, customer experience).

3) Channels: How a company communicates with and reaches its Customer Segments to deliver a Value Proposition. Communication, distribution and sales Channels comprise a company's interface with customers. Channels can be direct or indirect, owned or partner channels.

4) Customer Relationships: The types of relationships a company establishes with specific Customer Segments.

5) Revenue Streams: The cash a company generates from each Customer Segment.

6) Key Resources: The most important assets required to make business model work. These resources allow an enterprise to create and offer a Value Proposition, reach markets, maintain relationships with Customer Segments, and earn revenues. Key resources can be physical, financial, intellectual, or human. They can be owned or leased by the enterprise or acquired from key partners.

7) Key Activities: The most important things a company must do to make its business model work. They are the actions that are required to create and offer a Value Proposition, reach markets, maintain Customer Relationships and earn revenues.

8) Key Partnerships: The network of suppliers and partners that make the business model work.

9) Cost Structure: All costs incurred to operate a business model.

Osterwalder \& Pigneur (2002) and Sonninen (2016) assess the overall integrity of the business model is very important but seeing all its components in detail can also reveal interesting paths for innovation and renewal. An effective way to do this is to combine a classic analysis of strengths, weaknesses, opportunities, and threats (SWOT) through the Business Model Canvas (Humphrey, 2005).

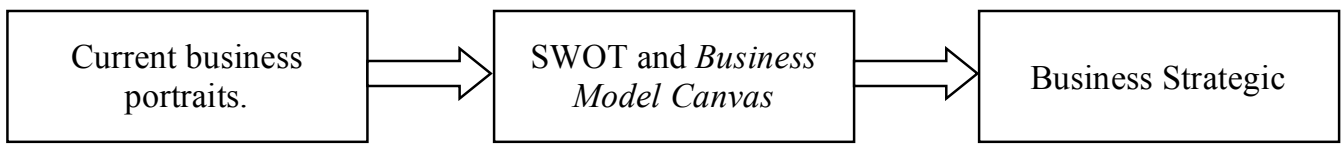

Fig. 2. Business model development process

Business model development process as follow (Humphrey, 2005; Osterwalder \& Pigneur, 2010):

1) Current business portraits. Identify the current business model. Portrait of the nine elements of the business model or conditions that occur.

2) Perform SWOT analysis (Strength, Weakness, Opportunities, and Threat) on nine elements of Business Model Canvas.

3) Make improvements to the Business Model Canvas and/or make a prototype for creating business strategic.

\section{RESEARCH METHODS}

This research study has opted to apply descriptive analysis along with qualitative design method. Unit analysis of this paper is PT. Timah Agro Manunggal (PT. TAM) in Bangka Belitung Island Province in Indonesia. Primary data were collected through in-depth interviews and 
observations, while secondary data were obtained through documentations already available in places like library to study about agribusiness company on reclamations sector. Data collecting process included participant activity and getting along processes in research location as well as data logging. In the data logging process, three kinds of techniques were performed namely participatory and non-participatory observations and in-depth interviews.

Through in-depth interviews, information or opinions were collected from a director, managers and staff of PT. TAM, and we collected form community and government for compare and validation data. In addition to the interview method, we also conduct a group discussion (FGD) forum. The process of collecting data and information through the FGD discusses a related problem nine blocks of business model canvas. This research applied nonprobability sampling i.e. purposive sampling technique. Meanwhile, for data analysis, reduction, data display, and conclusion techniques were applied.

\section{RESULTS AND DISCUSSION}

PT. Timah Agro Manunggal (TAM) is a subsidiary of PT. TIMAH. PT. TAM is included in the fourth business pillar of PT TIMAH is competence-based businesses, which was founded as the company's effort to diversify its business. In future, this subsidiary engaging in agribusiness, such as agriculture. livestock as well as reclamation and agriculture land arrangement services are expected to be one of the new sources of the Company's revenue.

PT. TAM has a responsibility with PT TIMAH through the transformation of ex-mining land into environmentally friendly agribusiness land and securing the potential reserves of PT TIMAH. Core competencies of PT. TAM is a business in agriculture, animal husbandry, trade related to agribusiness, development for agricultural, services related to agribusiness.

Products offered by PT. TAM includes; (1) Food crop agricultural products; (2) agricultural products for animal feed plants; (3) livestock; (4) manure; (5) industrial crop agricultural products. While the services offered by PT. TAM is managing the ex-mining land reclamation project and structuring agricultural land and plantations in the tin ex-mining area.

Analysis of the external and internal business environment at PT. TAM refers to Strengths, Weakness, Opportunities and Threats (SWOT). After analysing the strengths, weaknesses, opportunities and threats that are owned and faced by PT. TAM, then is the design of BMC. According to Osterwalder \& Pigneur (2010) the design of BMC shows how to think about how a company produces nine blocks in BMC.

Murray \& Scuotto (2016) explains that the first thing that must be identified from the company is customer segments, second is to know the company's value propositions, third is who channels PT. TAM to help companies create company values. Fourth is customer relationships which are where companies give space for communication to customers. The fifth is to identify revenue streams received by the company that becomes profits for PT. TAM. The sixth step is to identify key resources that the company has to determine the strategy for carrying out key activities. Seventh is identifying the activity key. The eighth step is identifying key partners, namely the main partners owned by PT. TAM.

Finally, the ninth step is to identify and formulate the cost structure of PT. TAM, which is the key to success in managing the company in order to be able to increase the profitability of the company. 
Table 1. SWOT Analysis of PT. Timah Agro Manunggal (TAM)

\begin{tabular}{|c|c|c|}
\hline Internal and External Analysis & $\begin{array}{l}\text { Strengths (S) } \\
\text { 1. PT. TAM is a subsidiary of PT. } \\
\text { TIMAH where is a post-mining } \\
\text { reclamation company } \\
\text { 2. Collaboration with society and } \\
\text { government } \\
\text { 3. PT. TAM produces agricultural } \\
\text { and livestock products } \\
\text { 4. Agricultural products are used } \\
\text { to support reclamation services } \\
\text { 5. PT. TAM does not have many } \\
\text { competitors in the Sumatra } \\
\text { region }\end{array}$ & $\begin{array}{l}\text { Weakness (W) } \\
\text { 1. The market for reclamation, } \\
\text { agricultural products, and animal } \\
\text { husbandry are still limited } \\
\text { 2. The conditions for supporting } \\
\text { facilities and infrastructure for } \\
\text { reclamation are still not optimal } \\
\text { 3. Do not have own plant seeds for } \\
\text { post-mining land reclamation } \\
\text { services } \\
\text { 4. There are no experts to manage } \\
\text { heavy equipment for reclamation }\end{array}$ \\
\hline $\begin{array}{l}\text { Opportunities (0) } \\
\text { 1. There are not many competitors } \\
\text { 2. Society and government have } \\
\text { synergized in reclamation, } \\
\text { agricultural products and } \\
\text { livestock } \\
\text { 3. Have opportunities for } \\
\text { exploration to other mining } \\
\text { companies }\end{array}$ & $\begin{array}{l}\text { S-O Strategy: } \\
\text { 1. PT. TAM synergizes with the } \\
\text { community, government and } \\
\text { non-governmental } \\
\text { organizations (NGOs) } \\
\text { 2. Market expansion to the } \\
\text { national scale } \\
\text { 3. Sustainable agricultural and } \\
\text { livestock product innovation } \\
\text { program }\end{array}$ & $\begin{array}{l}\text { W-O Strategy: } \\
\text { 1. PT. TAM Entering a wider } \\
\text { market and not only PT. TIMAH } \\
\text { only } \\
\text { 2. Customer Focus Program } \\
\text { 3. Program to increase the } \\
\text { capability of company resources }\end{array}$ \\
\hline $\begin{array}{l}\text { Threats (T) } \\
\text { 1. The cost of ex-mine land } \\
\text { reclamation services is very } \\
\text { expensive because the price of } \\
\text { seeds and fertilizers is very } \\
\text { expensive } \\
\text { 2. PT. TAM is still using a sub- } \\
\text { contractor to reclaim ex-mining } \\
\text { land } \\
\text { 3. Unclear land ownership rights } \\
\text { between ex-mining areas and } \\
\text { communities } \\
\text { 4. Not all land can be reclaimed }\end{array}$ & $\begin{array}{l}\text { S-T Strategy: } \\
\text { 1. Community empowerment- } \\
\text { based collaboration program } \\
\text { 2. Agricultural product and animal } \\
\text { husbandry development } \\
\text { program } \\
\text { 3. Program to increase the } \\
\text { capacity of machines or heavy } \\
\text { equipment for the needs of ex- } \\
\text { mine land reclamation services } \\
\text { 4. Improving the quality economy } \\
\text { of the community around the } \\
\text { company }\end{array}$ & $\begin{array}{l}\text { W-T Strategy: } \\
\text { 1. Strategy for developing } \\
\text { partnerships with stakeholders } \\
\text { 2. Improving the quality of } \\
\text { agricultural production and } \\
\text { livestock through innovation } \\
\text { 3. Activity program to strengthen } \\
\text { social networks and } \\
\text { partnerships with corporate } \\
\text { social responsibility activities. }\end{array}$ \\
\hline
\end{tabular}

After conducting in-depth interviews with key informants, the results of analysis from nine BMC blocks at PT. TAM, the description of the findings of this study is explained as follows:

\section{Customer Segment}

Based on the results of interviews with informant, PT. TAM is a mining subsidiary of PT. TIMAH, which implements the parent company obligation, is to be able to reclaim land after tin mining in the Mining Business License Area. PT. TIMAH is obliged to reclaim ex-mining land and tin mining operations. Because the impact caused is very damaging to the surrounding environment, so that it harms the community, living things around the mining area, and environmental damage. According to Director of PT. TAM, the current customer ex-mine land reclamation is only PT. TIMAH. The company has reclaimed 100 hectares of land damaged by ex-mining in the Bangka Belitung Islands Province. 


\section{Value Propositions}

The value proposition given to consumers in business practices at PT, TAM is a reclamation of tin ex-mining land. PT. TAM has the value of collaboration that synergies between the community, the government and non-governmental organizations (NGOs) around the company. Agricultural products in the reclamation area are utilized by the community and the local government.

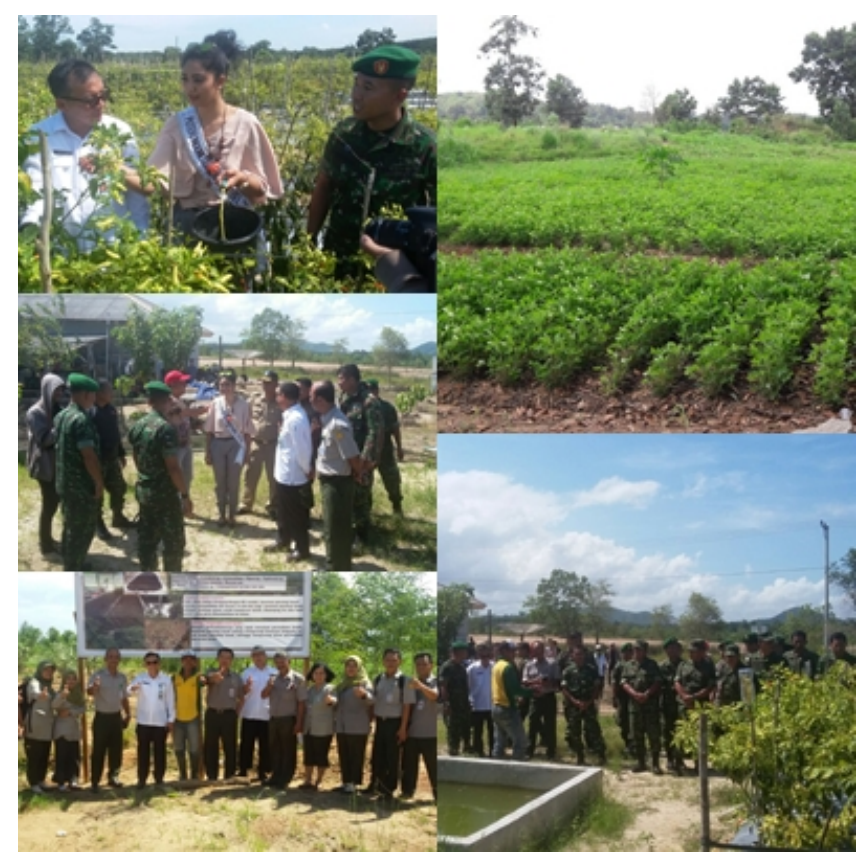

Fig. 3. Agricultural products in the ex-mine reclamation area of PT. TIMAH

\section{Channels}

Channels used to reach communication with PT. TIMAH is strong because PT. TAM is a subsidiary of PT. TIMAH. According to Osterwalder \& Pigneur (2010), there are several functions of channels that are business activities in buying more specific products or services. In this case, the ex-mine land reclamation service. Then, the main product of PT. TAM is a reclamation service which is a unique and specific business activity. PT. TIMAH requires exmining land reclamation, so that the channels formed are very strong and communicative. Because there are not many companies engaged in reclamation.

\section{Customer Relationships}

Based on the results of interviews, there is good communication between PT. TAM with PT. TIMAH as a mining company that uses ex-mine reclamation services. PT. TAM accompanies and serves customers cooperatively. This means that the elements of personal assistant and personal assistants who are dedicated in the elements of Customer Relationships have been fulfilled, and in accordance with the theory put forward by (Osterwalder \& Pigneur, 2010). 


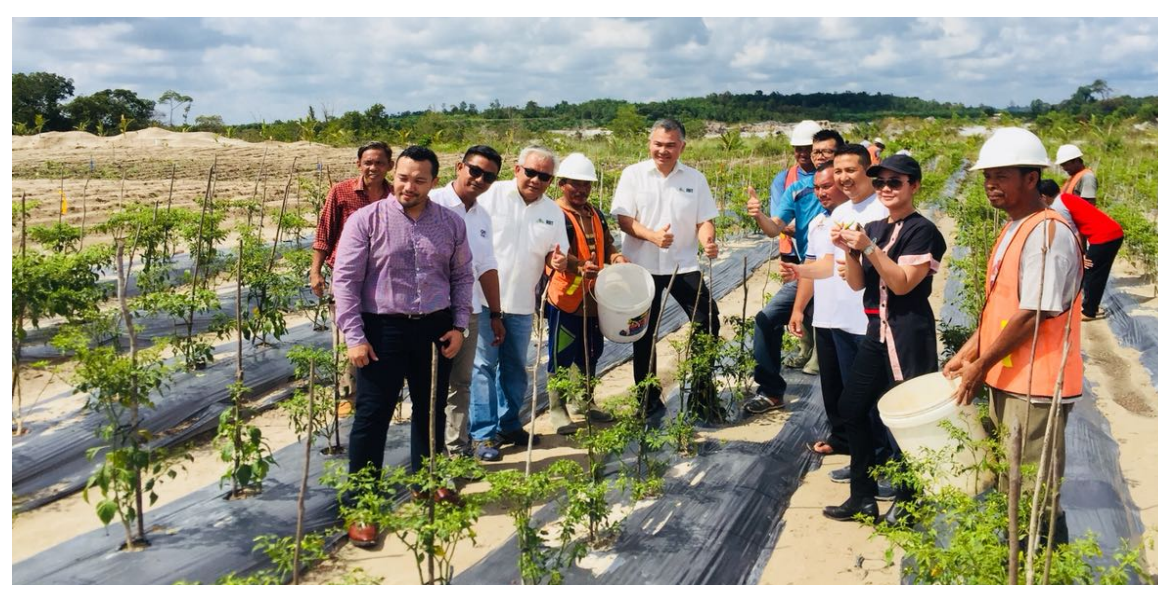

Fig. 4. Assistance during ex-mining reclamation of PT. TIMAH

\section{Revenue Streams}

PT. TAM receives revenue from the ex-tin mining land reclamation services. In addition, other income also comes from the agribusiness and livestock sector. Based on the results of the interview, it was found that PT. TAM has other products besides ex-mine land reclamation, i.e.:

a) Reclamation plant seeds, which are seeds used for planting when post-mining land has been reclaimed.

b) Compost fertilizer, which is one of the organic fertilizers made by PT. TAM is made from the process of decomposing the remnants of organic materials such as plants and from animal waste.

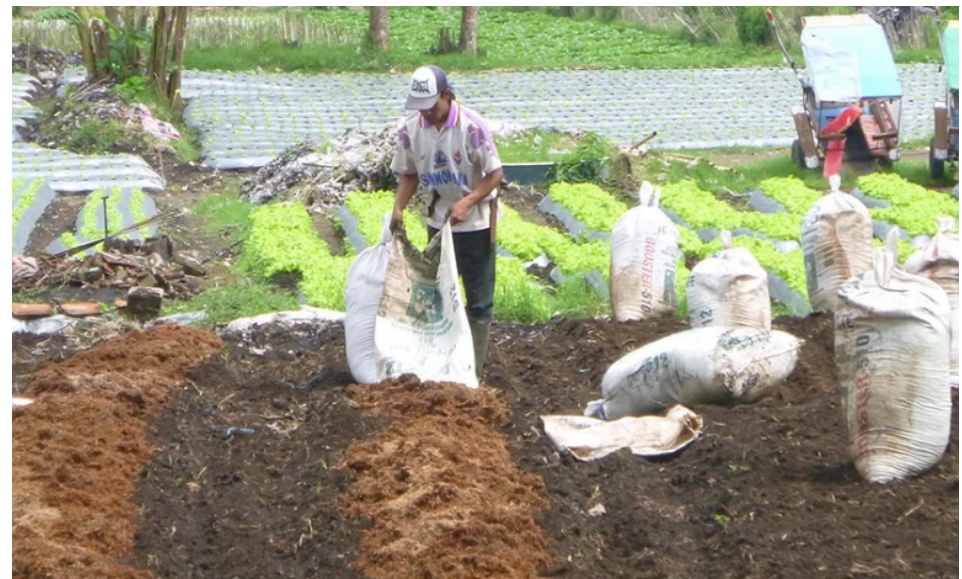

Fig. 5. Making compost fertilizer at PT. TAM

c) Business for rent of agricultural land, PT. TAM rents agricultural land to other companies. This is one of the sources of income of PT. TAM. Through the benefits obtained, the company increased the resources in the form of heavy equipment purchases for the purposes of ex-mine land reclamation.

\section{Key Resources}

The main resource at PT. TAM is categorized into four i.e.

a) Physics includes buildings, machinery, agricultural land and livestock, heavy equipment such as bulldozers, tractors, and operational vehicles.

b) Intellectuals include intellectual property in the form of standard operational procedures for reclamation, compost patent rights, trademarks. 
c) Human resources include human resources, such as experts in the field of mining, experts in agriculture, experts in the field of animal husbandry, experts in the field of heavy equipment and the quality of geological controversies and soil science.

d) Financial includes profit, cash flow. Without strong financial support, the business will not run well.

\section{Key Activities}

Key Activities at PT. TAM can be classified into two category;

a) Production which includes planting seeds for reclamation and compost fertilizer.

b) PT. TAM implements a system of collaboration with community empowerment.

c) Problem solving, meaning activities related to problems that arise from the product. An example is environmental damage caused by tin mining.

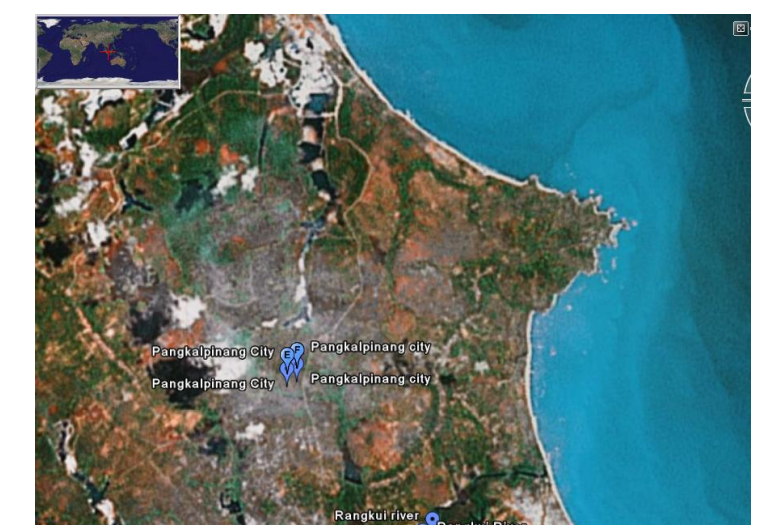

Fig. 6. Ex-mines in the Bangka Region are seen from satellites

\section{Key Partnerships}

Based on the results of the interview, PT. TAM uses partners to supply heavy equipment for post-mining land reclamation activities. The company initially offered people who owned heavy equipment because it was based on the principle of PT. TAM, namely community empowerment.

\section{Cost Structure}

The biggest cost structure is for human resources and operational costs. Employee salaries are a considerable cost because human resources are a very important resource. Operational costs are the biggest costs of the main activities that are spent, such as the cost of repairing and maintaining infrastructure and adding facilities. Based on the results of the interview, it can be said that PT. TAM uses the principle of cost driven, which means the business model of PT. TAM focuses on reducing costs as low as possible. This approach aims to maintain a leaner cost structure, using value propositions at low prices. 
Table 2. Business Model of PT. Timah Agro Manunggal uses Business Model Canvas (BMC)

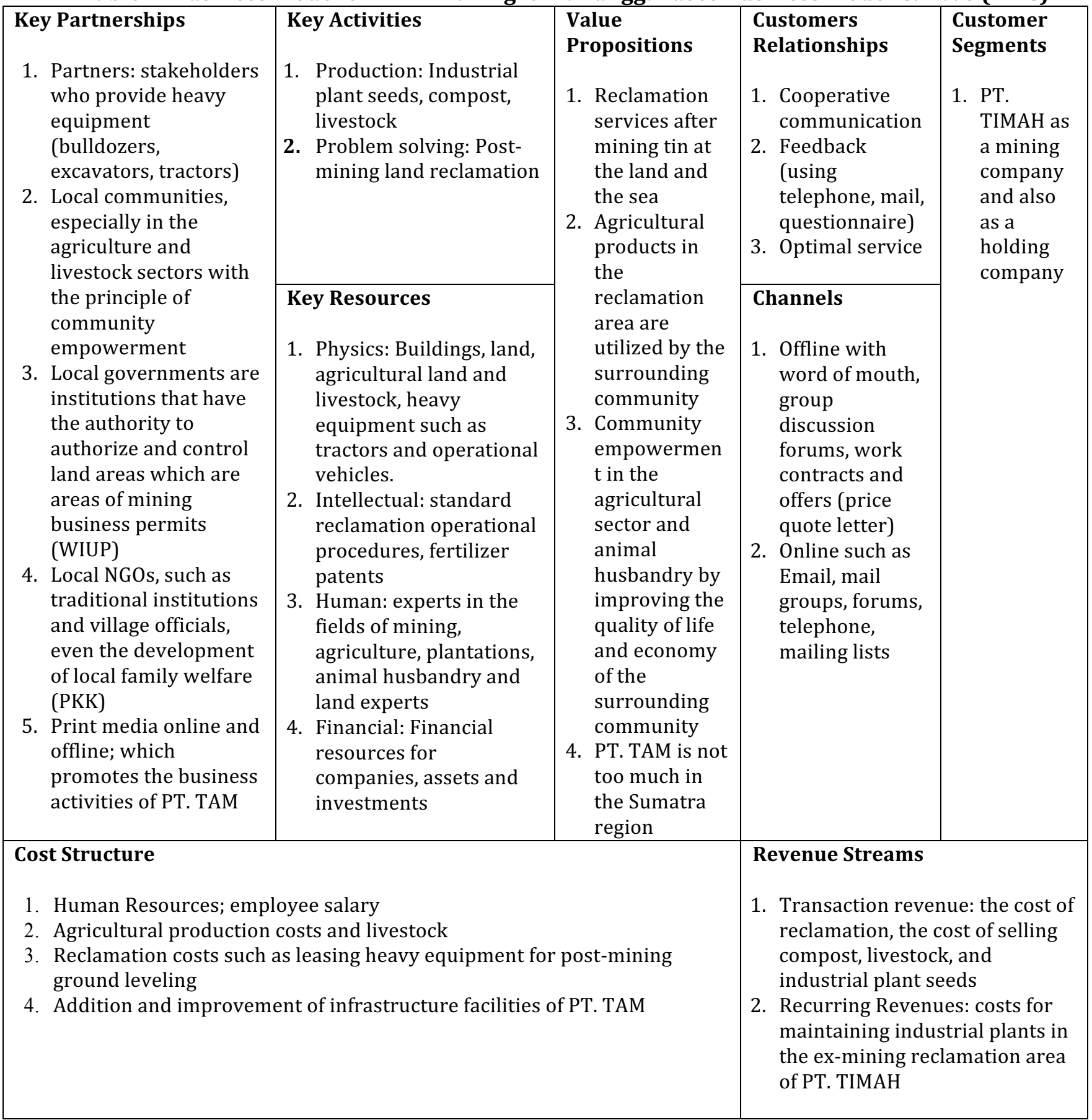

The canvas model business is a tool that allows us to plan new businesses with nine aspects, namely customer segments, value propositions, channels, customer relationships, revenue streams, key resources, key activities, key partners and cost structure. Based on result and discussion, BMC can help the parties involved by starting to see the form of business they have, analyzing the business model and developing the business according to the process flow. This canvas model business makes it very easy to decide to take strategic steps for the business being undertaken.

Based on the results of the Business Model canvass design, the strategy for developing agricultural products and livestock is suitable for PT. TAM, with efforts to focus on the 
livestock sector and agribusiness agriculture, and through the strategy of developing market share (market penetration) in the reclamation sector.

Based on the results of the research and discussion described earlier, it can be concluded that the business development strategy of PT. TAM can be developed as one of the efforts to establish the excellence of PT. TAM. The strategy that needs to be done by PT. TAM is as follows:

a) Conduct marketing strategies, to see a clear target market

b) Conduct a collaboration strategy with PT. TIMAH, Society, Government, Academics, Media, and Working Partners of PT. TAM.

c) Optimizing partnership relationships with stakeholders. The hope is to maximize the planning of the development of the business model of PT. TAM in the long term with various coordination efforts with stakeholders.

\section{CONCLUSION}

1. PT. TAM needs to pay attention to every activity or activity in its business practices and develop business strategies using the Business Model Canvas approach. PT. TAM needs to provide more value for products and services offered to provide satisfaction to consumers, especially PT. TIMAH as the parent company. PT. TAM must further improve the quality of channels to ensure customer service that impacts on customer trust.

2 For further research, it is hoped that not only focus on giving strategies. But you can add it again, like measuring the feasibility of a product to find out whether the product is feasible or not to run. In addition, it is also necessary to apply Business Model Canvas to other types of companies, so that it can be known whether research in other companies can use this Business Model Canvas or not.

\section{Reference}

Hanshaw, N., \& Osterwalder, A. (2016). The Business Model Canvas. Strategyzer. https://doi.org/10.1017/CB09781107415324.004

Humphrey, A. S. (2005). SWOT Analysis for Management Consulting. SRI Alumni Association Newsletter.

Johnson, E. A. J. (2012). Business Model Generation: A Handbook for Visionaries, Game Changers, and Challengers - By Alexander Osterwalder and Yves Pigneur. Journal of Product Innovation Management, 29(6), 1099-1100. https://doi.org/10.1111/j.1540-5885.2012.00977_2.x

Maurya, A. (2014). Why Lean Canvas vs Business Model Canvas ? Running Lean, (May 2009), 1-18.

Murray, A., \& Scuotto, V. (2016). The Business Model Canvas. Symphonya. Emerging Issues in Management, O(3), 94-109. https://doi.org/10.4468/2015.3.13MURRAY.SCUOTTO

Osterwalder, A. (2004). The Business Model Ontology - A Proposition in a Design Science Approach. Business, Doctor, 1-169. https://doi.org/10.1111/j.1467-9310.2010.00605.x

Osterwalder, A., \& Pigneur, Y. (2002). An e-business model ontology for modeling e-business. 15th Bled Electronic Commerce Conference, June 17-19, 12. https://doi.org/10.1.1.16.633

Osterwalder, A., \& Pigneur, Y. (2010). Business Model Generation. A Handbook for Visionaries, Game Changers, and Challengers. https://doi.org/10.1523/JNEUROSCI.0307-10.2010

Sonninen, A. (2016). Strategic Management: Business Model Canvas for Start-Up Company.

Teece, D. J. (2010). Business models, business strategy and innovation. Long Range Planning, 43(2-3), 172-194. https://doi.org/10.1016/j.lrp.2009.07.003

Toro-Jarrín, M. A., Ponce-Jaramillo, I. E., \& Güemes-Castorena, D. (2016). Methodology for the of building process integration of Business Model Canvas and Technological Roadmap. Technological Forecasting and Social Change, 110, 213-225. https://doi.org/10.1016/j.techfore.2016.01.009 
Vial, V. (2016). A Business Model Canvas for Social Enterprises. Sains Humanika, 28(1-2), 1-8. https://doi.org/10.11113/sh.v8n1-2.825

Zolnowski, A., Weiß, C., \& Böhmann, T. (2014). Representing service business models with the service business model canvas - The case of a mobile payment service in the retail industry. In Proceedings of the Annual Hawaii International Conference on System Sciences (pp. 718-727). https://doi.org/10.1109/HICSS.2014.96 